\title{
Radiaxial-fibrous and fascicular-optic Mg-calcitic cave cements: a characterization using electron backscattered diffraction (EBSD)
}

\author{
Detlev K. Richter ${ }^{1}$, Adrian Immenhauser ${ }^{1}$, Rolf D. Neuser ${ }^{1 *}$, and Augusto Mangini ${ }^{2}$ \\ ${ }^{1}$ Institut für Geologie, Mineralogie und Geophysik, Ruhr-Universität-Bochum, D-44801 Bochum \\ ${ }^{2}$ Forschungsstelle Radiometrie, Heidelberger Akademie der Wissenschaften Im Neuenheimer Feld 229, 69120 Heidelberg
}

\begin{abstract}
Electron backscattered diffraction (EBSD) applied to crystal fabric research in speleothems aids in our understanding of the origin of those fabrics. A significant advantage of this approach is the three dimensional data set of crystal c-axes. Here, we show a rare case of both convergent (radiaxial-fibrous) and divergent (fascicular-optic) orientations of the c-axes in pool calcites. The seemingly defective structure of the calcite lattice resulting in radiaxialfibrous crystal orientations is probably caused by differential incorporation of $\mathrm{Mg}$ during crystal growth. The observation that radiaxial-fibrous and fascicular-optic fabrics co-exist in the same pool environment is remarkable and documents the complexity of the system.
\end{abstract}

Keywords: Mg-calcite; cave cements; radiaxial-fibrous; fascicular-optic; EBSD

Received 14 August 2014; Revised 27 October 2014; Accepted 3 November 2014

Citation: Richter D.K., Immenhauser A., Neuser R.D. and Mangini A., 2015. Radiaxial-fibrous and fascicular-optic Mg-calcitic cave cements: a characterization using electron backscattered diffraction (EBSD). International Journal of Speleology, 44 (1), 91-98. Tampa, FL (USA) ISSN 0392-6672 http://dx.doi.org/10.5038/1827-806X.44.1.8

\section{INTRODUCTION}

Most calcitic speleothems are characterized by a crystal structure of isometric (equicrystalline) grains or oblong crystals (columnar to fibrous) with different length in the growth direction (Frisia et al., 2000; Railsback, 2000; Self \& Hill, 2003; Frisia \& Borsato, 2010). According to Folk \& Assereto (1976) two subtypes of calcites with oblong crystals are distinguished: Such with (i) the c-axis oriented along the longitudinal extent of the calcite (length-fast) and such with (ii) the c-axis approximately perpendicular to the longitudinal extension of the calcite (length-slow; a rare subtype). For more detail, the reader is referred to Onac (1997) for a comprehensive review on the crystal types and morphologies of carbonate and sulfate minerals.

Given that some of the calcite crystals building speleothems display a radial fibrous texture (type 2.1.1 or 2.1.2 in Self \& Hill, 2003) and show strong undulatory extinction, a quantitative understanding of the spatial c-axis orientation in the crystals can be of particular importance. For an accurate characterization of the oblong calcites with different undulatory extinction the reader is referred to Kendall (1985) who established a classification for marine cements (Fig. 1). Accordingly, three cement types require attention in this context: (i) such with divergent c-axes in growth direction ("fascicular-optic"), (ii) such with converging c axes in growth direction ("radiaxialfibrous") and (iii) such with uniform c-axes ("radialfibrous"). Following this classification, Neuser \& Richter (2007) have presented oblong calcite crystals with converging and diverging c-axes in growth directions within stalagmites from caves located in dolostone host rock lithologies. Data obtained at these sites clearly documented that the Mg content of the drip waters is significant (Richter et al., 2011).

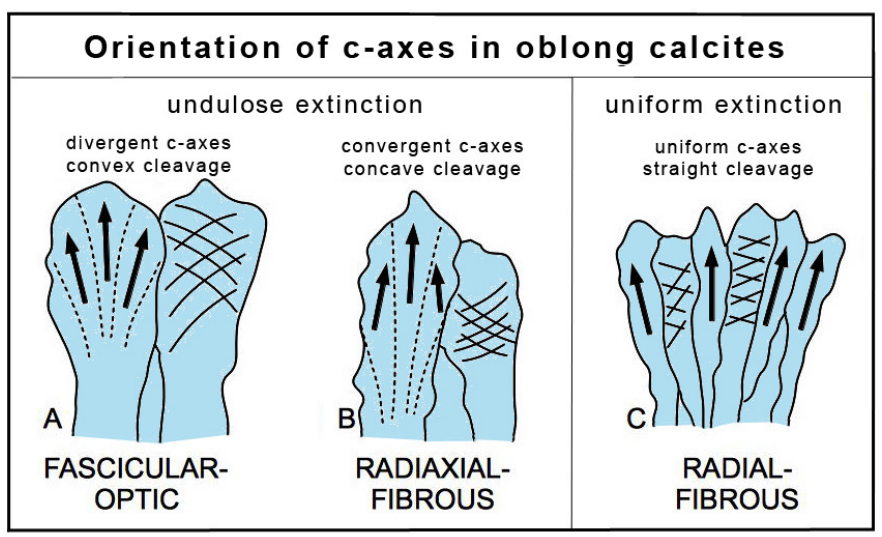

Fig. 1. Types of oblong calcite crystals according to internal orientation of the c-axis (modified after Kendall, 1985). Arrows: c-axis orientation; solid lines: cleavage cracks; dashed lines: subcrystal boundaries. 
In this study, two cave cements with different c-axis orientations in calcites from subaqueous environments (pools) of Zoolithen Cave (Germany) are presented and discussed in the context of their environment and crystallography.

\section{CAVE SETTING AND SAMPLE LOCATIONS}

The calcite samples were taken from rimstone pools of Zoolithen Cave, Germany, a cave being mainly known for its fossil vertebrate remnants (Heller, 1972). We only collected 6 samples due to the protection status of the cave. The cave is located in the Upper Jurassic Franconian dolostone (Frankendolomit) at Burggaillenreuth (E' Forchheim; Fig. 2A) above the Wiesent Valley, and exhibits a labyrinth shape with many lixiviations (most recent cave survey: Dreyer, 2000).

The entrance level of the Zoolithen Cave (Kataster$\mathrm{Nr}$. D 109) is located $455 \mathrm{~m}$ above sea level (the Wiesent Valley is $310 \mathrm{~m}$ above sea level). The mean temperature in the cave was previously documented in Tietz (1988) as $7.5^{\circ} \mathrm{C}$ for the $1977 / 78$ period, and by the Bochum Geology Group as $8-9^{\circ} \mathrm{C}$ since 2010. The two sampled rimstone pools (Fig. 2B) are found in the central part of the cave.
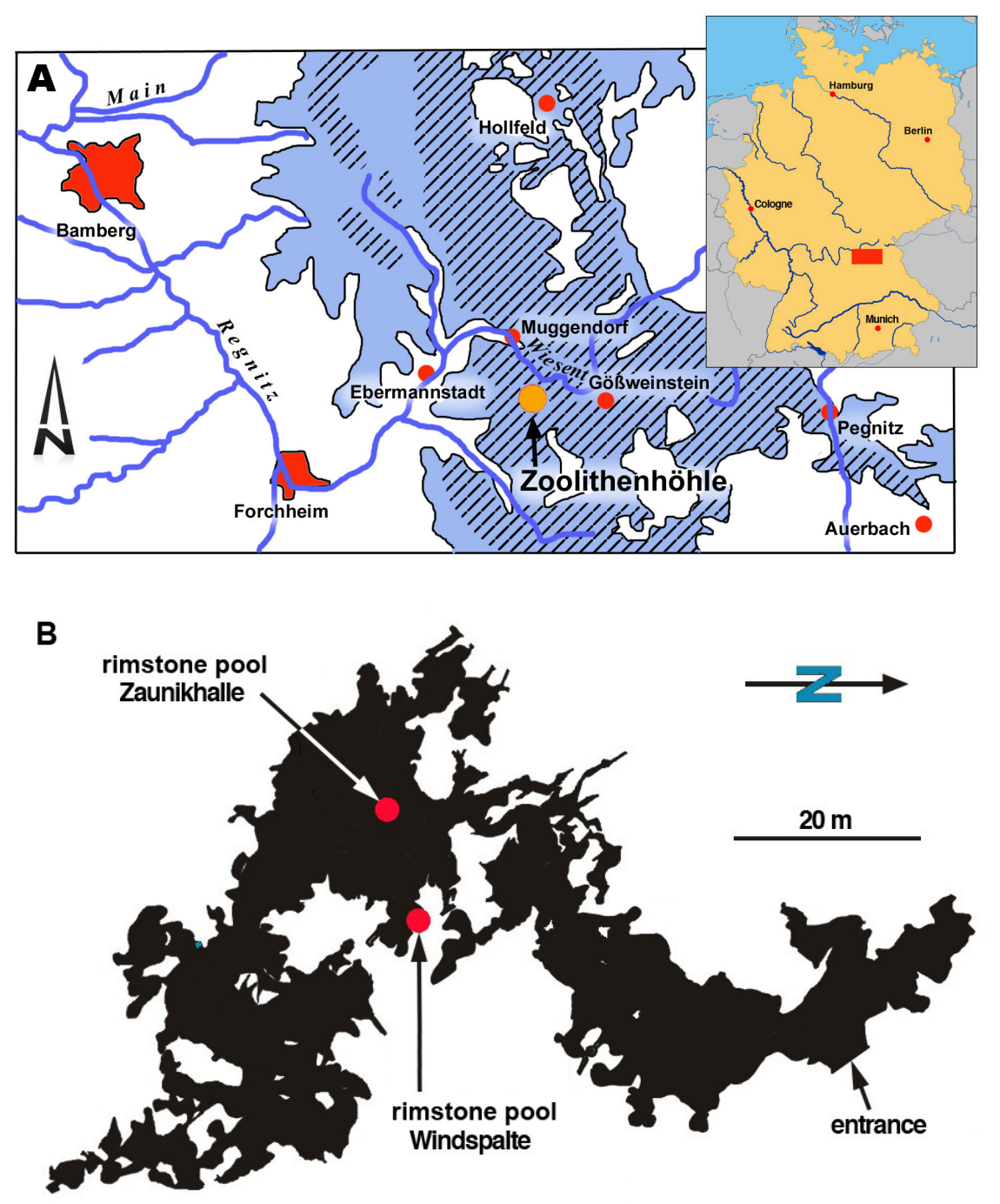

Fig. 2. Overview. A: Location of Zoolithen Cave in the Franconian dolomite (hatched area) of the Franconian Alb. B: Map of Zoolithen Cave (simplified after Dreyer, 2000) with markers for the location of the investigated rimstone pools (1: Zaunikhalle, 2: Windspalte).

\section{Location 1 (Zaunikhalle):}

In Zaunikhalle Room the largest rimstone pool extends NNE - SSW (5.3 m below the entrance level, length $=10.3 \mathrm{~m}$, maximum width $=3.2 \mathrm{~m}$, maximum depth $=0.88 \mathrm{~m}$; Fig. 3A). The black color of the rimstone is likely due to soot from torch activities carried out during the paleontological excavations by Esper from 1770 to 1790 (see Heller, 1972). Furthermore, recent construction (wood-piles for visitor paths) has affected the natural conditions of the Zaunikhalle at least temporarily.

\section{Location 2 (Windspalte):}

In Windspalte Room, $19 \mathrm{~m}$ below the cave entrance next to the visitor's path, between Zaunikhalle and Löwengrube, a second rimstone pool (now dry) was sampled $(10 \mathrm{~m}$ below the entrance level, length $=1.7 \mathrm{~m}$, width $=1.4 \mathrm{~m}$, maximum depth of the now empty basin $=0.35 \mathrm{~m}$; Fig. 3B). This locality 2 corresponds to the extraction point of stalagmite ZOO2 studied at high-resolution by Wurth (2002).

\section{ANALYTICAL WORK CONVENTIONAL METHODS}

For documentation, the outer contours of the filigreed cements have been cleaned in an ultrasonic bath and afterwards been sputtered with gold to prevent charging in a high-resolution field emission scanning electron microscope (HR-FESEM) type LEO/ZEISS 1530 Gemini.

Polished thin sections were prepared to obtain first information concerning the internal structures of the cement crystals using a polarizing microscope.

The mineral compositions of the carbonate phases were obtained by X-ray diffraction (XRD) using a pananalytical MPD diffractometer equipped with a copper tube, $0.5^{\circ}$ divergent and diffracted beam, 0.04 rad soller slits, and a secondary graphite monochromator as documented by Mioa et al. (2009). Methodically ground samples with quartz powder as internal standard have been measured by a diffraction angle range of $26-38^{\circ}(2 \Theta)$, identifying each $\mathrm{d}_{(104)}$ value of the rhombohedral carbonates in terms of their $\mathrm{Ca} / \mathrm{Mg}$ distribution (Füchtbauer \& Richter, 1988).

Carbon and oxygen isotopic compositions of the carbonates were determined with a delta S mass spectrometer (Finnigan MAT) and calibrated against V-PDB (standards: $\mathrm{CO}-1$ and $\mathrm{CO}-8$ ). The 


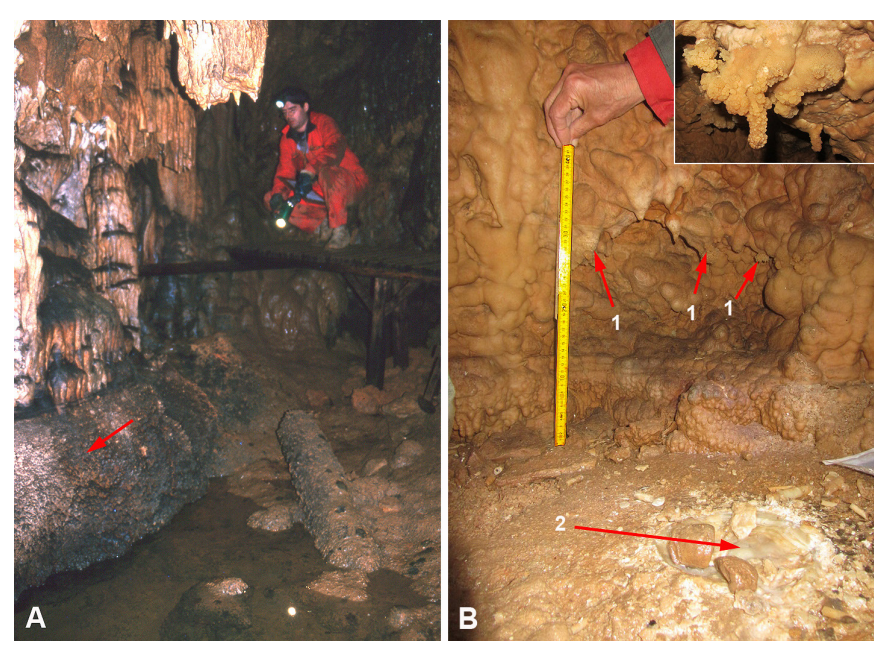

Fig. 3. Sampled rimstone pools: A: Zaunikhalle (arrow: sampled rimstone crust); B: Windspalte (arrows (1) point to mural calcite crusts of the paleobasin, detailed picture see upper right corner; arrow (2) points to sampling site of stalagmite ZOO2). Images Zaunikhalle courtesy of R. Dreyer, Windspalte courtesy of M. Harder.

$1 \sigma$-reproducibility of the measurements is $0.04 \%$ o $\mathrm{V}-\mathrm{PDB}$ for $\mathrm{\delta}^{13} \mathrm{C}$ and $0.08 \% \mathrm{~V}-\mathrm{PDB}$ for $\delta^{18} \mathrm{O}$, respectively.

Cation and anion concentration were measured at the University of Heidelberg at the Institute for Ecologic Geochemistry by A. Schröder-Ritzrau. For the analysis of the cations each sample was acidified with $100 \mu 1$ of nitric acid. The subsequent analysis was performed using an ICP-OES Vista MPX by Varian. NIST $1643 \mathrm{e}$ was used as a standard providing a reproducibility between 2 and $3 \%$ for $\mathrm{Na}^{+}, \mathrm{K}^{+}, \mathrm{Ca}^{2+}, \mathrm{Mg}^{2+}$, and $\mathrm{Sr}^{2+}$. An ion chromatograph type DX120 by Dionex company was employed for the anion measurements.

Age dating was performed using the Th/U-method at the Heidelberg Academy of Sciences. For each sample between 1 and $2 \mathrm{~g}$ were prepared at the clean laboratory and their ${ }^{238} \mathrm{U},{ }^{234} \mathrm{U},{ }^{232} \mathrm{Th}$, and ${ }^{230} \mathrm{Th}$ contents were determined using Finnigan Thermal Ionization Mass Spectrometry (TIMS) MAT 262 RPQ (for details see Frank et al., 2000).

\section{ELECTRON BACKSCATTERED DIFFRACTION}

The SEM-based EBSD - methodology was applied using the computer program "Channel5" (Day \& Trimby, 2004) in combination with the acquisition software "AZtec" by OXFORD Instruments. First, the surfaces of polished thin sections were chemomechanically etched for about 15 min with colloidal silica (OPS) to remove surface defects at an atomic scale (Massonne $\&$ Neuser, 2005). After coating with of a thin carbon layer the samples were examined using a SEM LEO/Zeiss Gemini 1530 with an EBSD detector (Nordlys, OXFORD Instruments). The SEM was operated at an $20 \mathrm{keV}$ accelerating voltage, a 60 micron aperture, a working distance of $25 \mathrm{~mm}$ and a tilt angle of $70^{\circ}$. EBSD allows a determination of the crystallographic orientation of down to about $500 \mathrm{~nm}$ sized crystals, thus information on the 3D structure of the sample in a micro- or nanometer range is provided (for details see Day \& Trimby, 2004). To eliminate analytical artifacts and to limit measurement errors, the crystals of the thin sections were scanned in a $1 \times 1 \mu \mathrm{m}$ dot matrix. Thus the smallest calcite crystals could be measured at a resolution of at least 100 points.

The scanned crystals were color-coded to better visualize their orientations, where the colors indicate angular deviation within crystal bundles. In addition, the crystal axes were plotted in a Schmidt net (lower hemisphere).

\section{SAMPLE MATERIAL}

The sample material was taken from localities with similar cave waters. The $\mathrm{Mg} / \mathrm{Ca}$ weight ratio of the recent water is nearly identical $(0.88$ versus 0.83$)$, but the saturation index of the dripwater in the rimstone pool of Windspalte is significantly higher than that of Zaunikhalle (0.87 versus 0.54$)$.

The studied rimstone pools are characterized by up to $5 \mathrm{~cm}$ (Loc. 2) and $50 \mathrm{~cm}$ (Loc. 1) thick calcitic cement crusts with a highly porous filigreed structure and small $(<1 \mathrm{~mm}$ to $2 \mathrm{~cm})$, leaf-like individual elements of calcite crystal bundles. Macroscopically, the thickest crusts of Zaunikhalle (Loc. 1) resemble subaquatic coralloids described and illustrated by Hill \& Forti (1997).

The sampled pool cements of Zaunikhalle reflect a Holocene to subrecent age because in thin section only a thin layer of clear calcite crystals is observed on the black crusts. U/Th dating of the crust yielded a corrected age of $5.7 \pm 4.0 \mathrm{ka}$. The imprecision was due to high proportion of ${ }^{232} \mathrm{Th}(1.36 \mathrm{ng} / \mathrm{g})$ and low amounts of ${ }^{238} \mathrm{U}(0.03051 \mu \mathrm{g} / \mathrm{g})$. The high Th concentrations are probably due to the presence of clay-sized insoluble components.

The calcitic cement crusts taken from the chamber wall of Windspalte correspond to a speleothem crust level of equal crystal formation in ZOO2 (Fig. 4), which according to U-Th datings (Fig. 4) were younger than

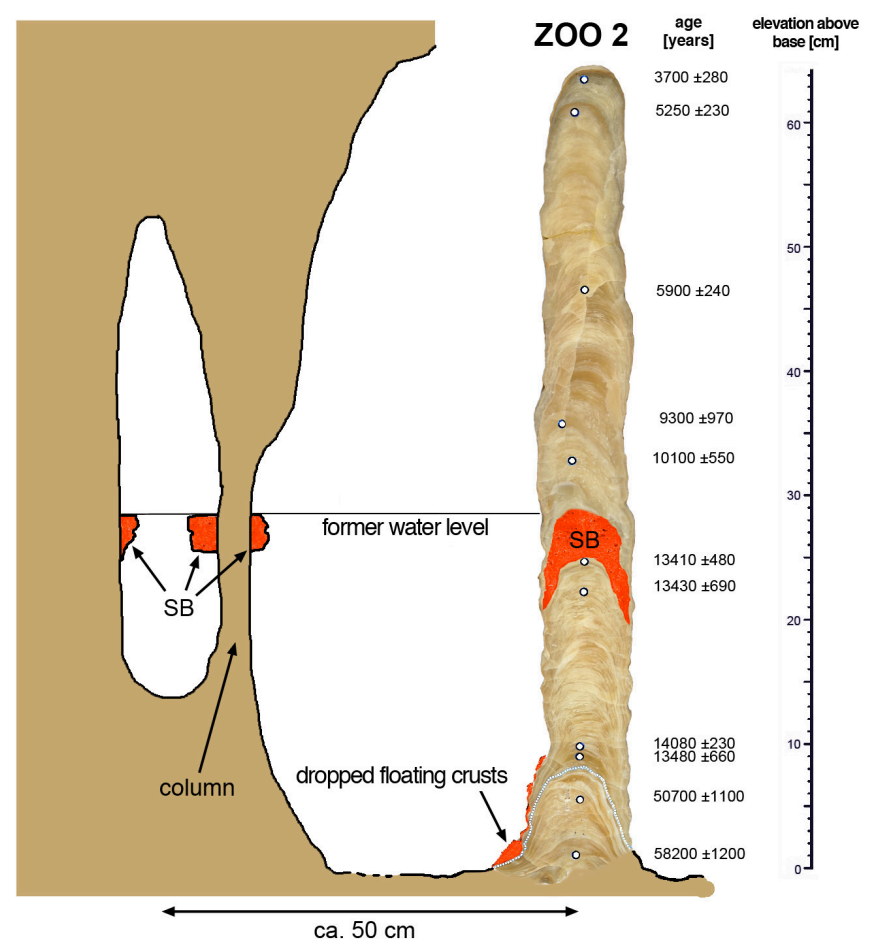

Fig. 4. Reconstruction of position of the rimstone crust areas of the fossil cave pools in relation to the palaeo-water level of Windspalte. Right image stalagmite ZOO2 with U/Th age data, left image chamber wall with a small column, SB: calcitic cement crusts of pool. 
$13 \mathrm{ka}$ and older than $10 \mathrm{ka}$ and probably correspond to the period of Younger Dryas (12.6 - $11.6 \mathrm{ka}$ BP). Under a similar calcite layer at the bottom of the dry rimstone pool a $<3 \mathrm{~cm}$ thin debris deposit is present (crusts, calcitic crystal bundles of the same type as in the rimstone pool of Zaunikhalle, fragments of flow stone, bones, and siliciclastic detritus all of which had fallen to the floor and were not collected in situ).

According to XRD-analyses the crystal crusts are composed of $\mathrm{Mg}_{4.8-5.7}$-calcite (Loc. 1) and $\mathrm{Mg}_{4.7-5.3}$-calcite (Loc. 2), respectively. These values are typical of calcite in dolomite caves (4-7 $\mathrm{mol}_{\mathrm{O}} \mathrm{MgCO}_{3}$ after Tietz, 1988 , 1.5-6 $\mathrm{mol} \% \mathrm{MgCO}_{3}$ by Neuser \& Richter, 2007). Only from strongly ventilated caves (abri) in dolostone host rocks, calcitic coralloids with up to $23 \mathrm{~mol} \% \mathrm{MgCO}_{3}$ have been reported (Niggemann et al., 1997).

The carbon and oxygen isotope composition of the calcitic cements of the rimstone pool of Zaunikhalle (Loc. 1) correspond to the data of the Pleistocene and Holocene stalagmites of Zoolithen Cave, while the calcites of the rimstone pool of Windspalte (Loc. 2) have relatively heavy $\delta^{13} \mathrm{C}$ values (Fig. 5). This could be indicative of a reduced microbial soil activity during the Younger Dryas in the Franconian Alb.

Two-dimensional microscopic observations under crossed polars of calcitic cement fans from both rimstone pools reveal an overall systematic extinction with a divergent orientation of the c-axes (Fig. 6A and B). But at a higher magnification, a finer, fibrous structure becomes visible where individual fibers are less than $100 \mu \mathrm{m}$ in width.

Judging from scanning electron microscope (SEM) analyses, the calcitic cement bundles of Loc. 1 are composed of ellipsoidal shaped crystal aggregates

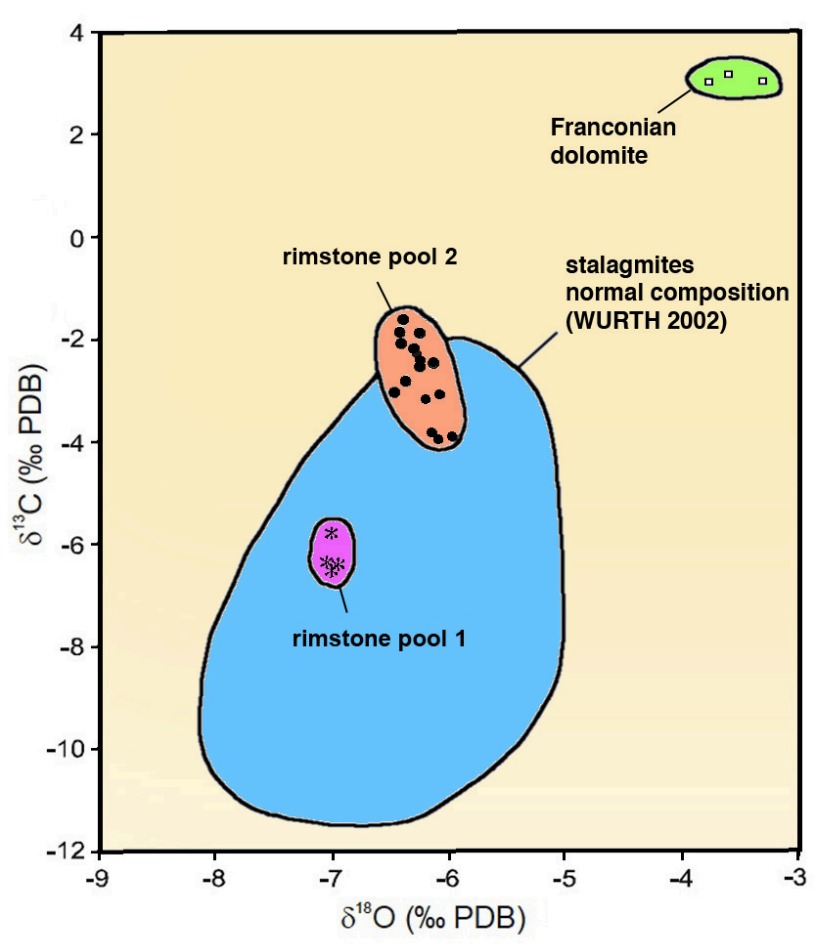

Fig. 5. Carbon and oxygen isotopic composition of calcite cements from Zaunikhalle (rimstone pool $1, *$ ) and Windspalte (rimstone pool $2, \bullet)$ compared to the fields of columnar calcite layers of stalagmites from Zoolithen Cave after Wurth (2002, shaded blue) and the dolostone host rock (shaded green, $\square$ ).
(Fig. 7A) with very steep rhombohedral faces at the tip of the fibers (Fig. 7B). The corresponding crystal aggregates of Loc. 2 show a botryoidal shape (Fig. 7C), and the fibers have less steep rhombohedral faces at their tips (Fig. 7D).

The fibers from both locations exhibit undulatory extinction, a feature that is particularly pronounced in the larger fibers of rimstone pool 2. In order to quantify the systematic change in lattice orientation of the calcite fibers, electron backscatter diffraction (EBSD) was applied.

\section{DATA PRESENTATION OF ELECTRON BACKSCATTERED DIFFRACTION}

The section perpendicular to the ellipsoidal (Loc. 1) or botryoidal (Loc. 2) shape of the bundles reveals a concentric color coding, were the red color indicates the strongest deviation from the central phase (blue) of the bundle (Fig. 8A/B and D/E). The result is a circular bundle-shaped orientation of the fibers. In sections parallel to the length of the bundle (Fig. $8 \mathrm{C} / \mathrm{F}$ ), the EBSD analysis reveals a divergent c-axis orientation in single fibers of Zaunikhalle calcites (Loc. 1), while the individual fibers of Windspalte calcites (Loc. 2) are characterized by a converging c-axis orientation.

The measured maximum angle of convergence of a fiber is $15^{\circ}$ while the angle of divergence of a fiber achieves a maximum of $7^{\circ}$. As documented in Fig. 8B and D, the internal bundle-like c-axis orientation is threedimensional as exemplified for individual fibers.

\section{INTERPRETATION AND DISCUSSION}

The filigreed structured calcite crusts of both rimstone pools are made up of a multitude of fiber bundles, which in turn are made of sub-individual calcite fibers. In the classification scheme of Maltsev (1996, cited in Onac, 1997), this structure corresponds to the "second-order individuals." This is accomplished by splitting the end of the calcites at the end of growth (especially in the bundles of the speleothems of Loc. 1).

Considering extensive literature the descriptions and classifications by Onac (1997) primarily refer to the calcite shape and the formation of the crystal surfaces. But as the crystals of the rimstone pools of Zoolithen Cave revealed an undulatory extinction, the EBSD method was applied for accurate quantification of the crystal lattice orientation. Obviously, the different patterns - divergent c-axis in the calcite fibers of Zaunikhalle pool, versus converging c-axis in the calcite fibers of Windspalte pool - requires attention.

Following Füchtbauer \& Richter (1975), an undulatory extinction in carbonate crystals is primarily due to their spatially heterogeneous chemical composition ( $\mathrm{Mg}$ in calcite, excess $\mathrm{Fe}$ and $\mathrm{Ca}$ in dolomite) and due to the frequency distribution and type of solid and fluid inclusions (especially non-carbonatic doping) or secondarily to epitactic displacement of recent mineral phases with undulatory extinction. Given that the calcites from the rimstone pools of Zoolithen Cave are virtually free of inclusions and evidence of epitactic 

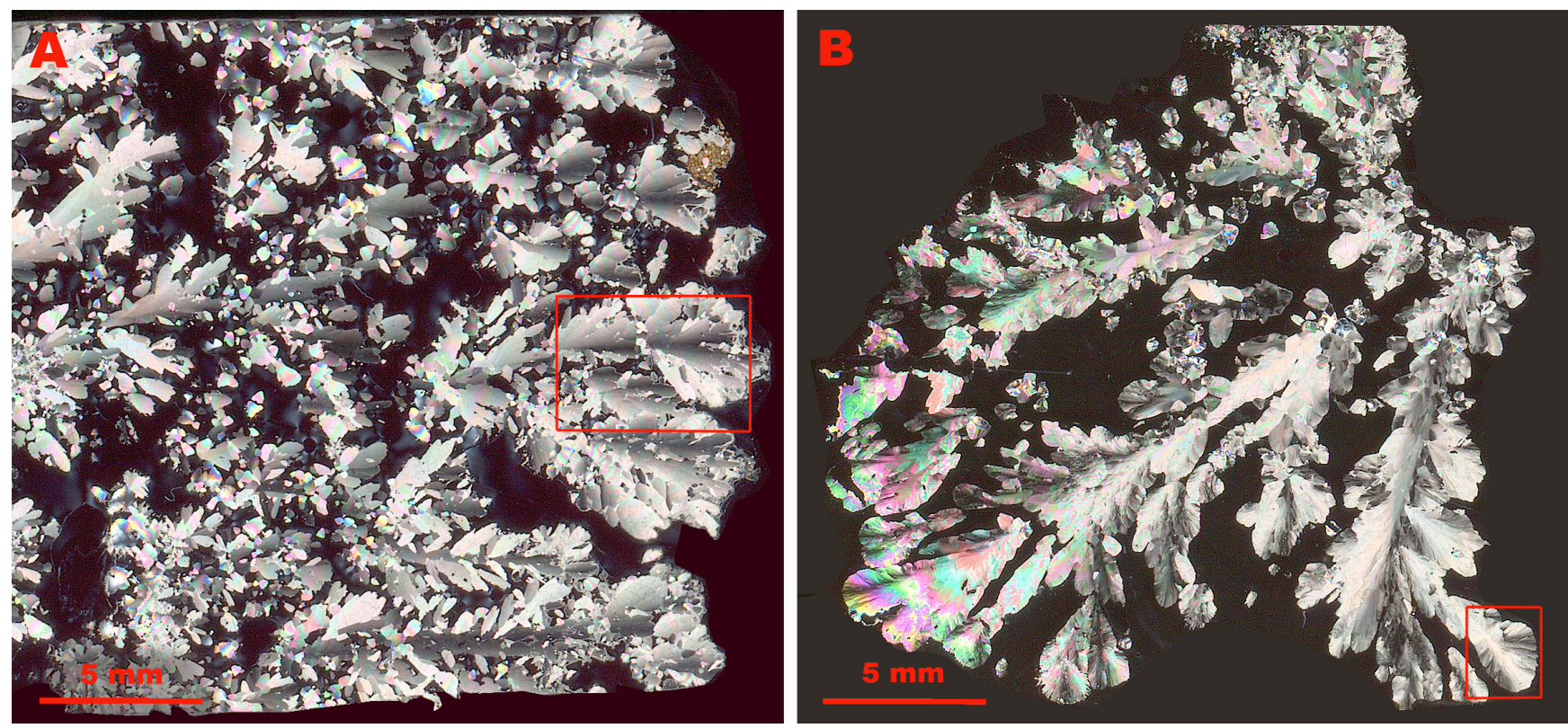

Fig. 6. Thin section images under crossed polarizers: A: calcitic cement Zaunikhalle, B: calcitic cement Windspalte.
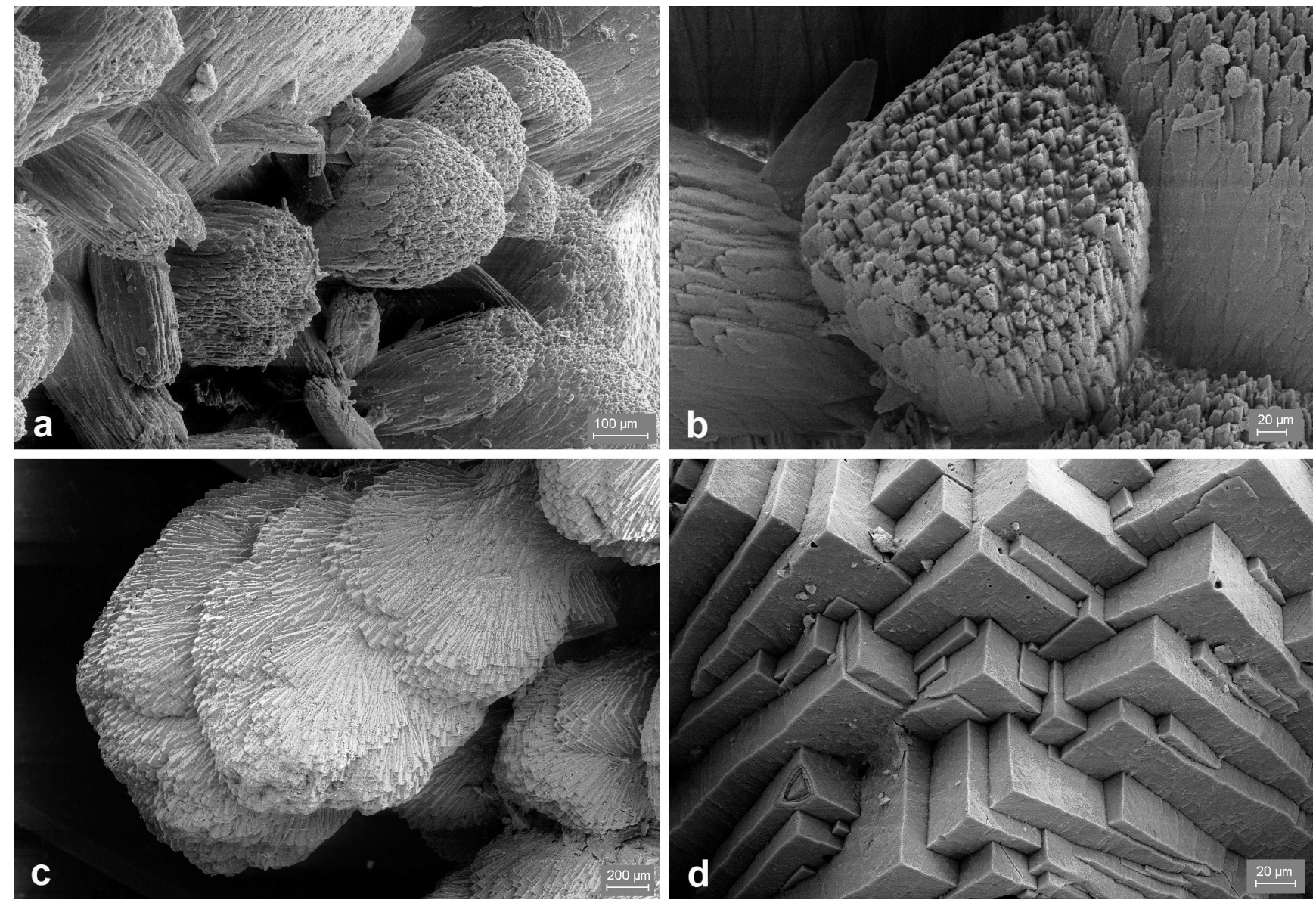

Fig. 7. Scanning electron micrographs of calcite bundles from Zaunikhalle (A: overview, B: detail of crystal tip) and from Windspalte (C: overview; D: detail of crystal tip).

recrystallization of a precursor mineral is missing, the third option, i.e. the spatially heterogeneous chemical composition offers itself as the most likely reason for the formation of undulatory extinction in calcite. This notion is consistent with the variable 4-6 $\mathrm{mol}_{0} \mathrm{MgCO}_{3}$ in the calcite of the rimstone pools. The divergent c-axis orientation in the calcite fibers of Zaunikhalle, however, is in contrast to the converging c-axis orientation in the calcite fibers of Windspalte. This contrasting pattern cannot be explained by $\mathrm{Mg}$ incorporation as both calcite fabrics have identical $\mathrm{Mg}$ contents. According to previous EBSD work by Richter \& Riechelmann (2008), stoichiometrically composed calcite fibers of cryogenical precipitates of the Malachitdom near Brilon equally reveal divergent c-axis orientation. Given these contrasting observations, other potential mechanisms require attention.

An alternative mechanism leading to diverging and converging crystal c-axes in the same precipitation environment might include the molarity of the pool 

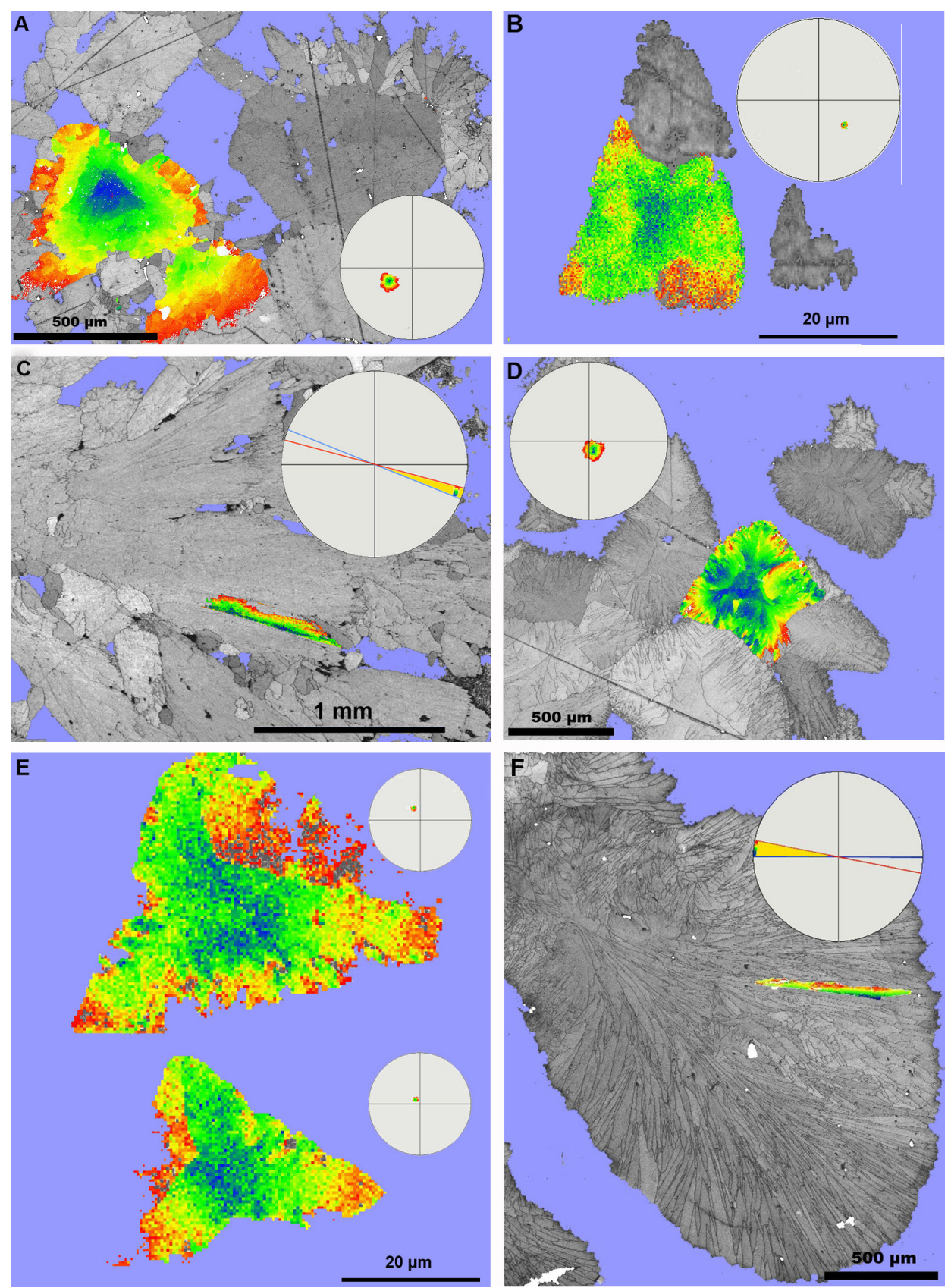

Fig. 8. Electron backscattered diffraction image with color code in sections perpendicular and parallel to the long orientation of the fiber bundle. Within the parallel sections $(C+F)$ same colors represent identical fiber directions. Within perpendicular sections $(A, B, D+E)$ same colors represent same angular deviations from the central axis. Angular deviation from blue to red is up to $10^{\circ}$. A, B + C calcites of Zaunikhalle: A: perpendicular section of fiber bundle; B: perpendicular section of single fiber; C: parallel section of single fiber. D, E + F calcites of Windspalte: D: perpendicular section of fiber bundle; E: perpendicular section across two single fibers; F: parallel section across single fibers.

waters. Evidence for this is based on ongoing cave monitoring. First data sets suggest, that the saturation index of the drip water in the rimstone pool of Windspalte is significantly higher than that of Zaunikhalle $(0.87$ versus 0.54 - SI calcite), a fact, that is likely to affect the growth rate. This may also explain the moderately higher carbon and oxygen isotope values of Windspalte calcites compared to Zaunikhalle calcites (see Fig. 5). Given \& Wilkinson (1985) suggest a stronger saturation and/or increased fluid flow to explain oblong calcite crystals, yet this is still no explanation of divergent versus convergent c-axis orientation as observed here.

A first possible line of circumstantial evidence for the mechanisms causing undulatory extinction of carbonate crystal textures comes from plain-light microscopy.
After determination of the general c-axis orientation in a calcite fiber using a compensator tube slot, or taking into account the orientation of the curved cleavage cracks, the observed extinction under crossed polarizers shifts to the opposite direction at converging c-axes (see Richter et al., 2011) during rotation of the fiber in the clockwise direction. The limitation of this approach is that data obtained data represent two-dimensional observations only. This is where the here applied EBSD method provides three-dimensional information.

In sections perpendicular to the long fiber orientation, the color coding indicates a circular pattern in three-dimensional convergence and divergence and a more linear pattern in two-dimensional convergence and divergence. Regarding the precipitates in the rimstone pool of Zoolithen Cave, EBSD analyses of the sample from Zaunikhalle displayed a threedimensional divergence, while the Windspalte sample exhibited a three-dimensional convergence. A filigreed structure of the calcitic cements of he rimstone pools, such as those presented here, is rather common in caves (e.g., Meyer \& Dorsten, 2009; their Fig. 8; "coral-like calcite crystals growth in the large rimstone pools of the "Kindergarten" of the Riesenberg Cave"), offering the availability of a large sample base from different caves for further analysis.

The filigreed structure of the speleothems (Fig. 6) is similar to the dendritic structure of flowstones and stalagmites (Frisia et al., 2000; Railsback, 2000). According to Frisia \& Borsato (2010) this is indicative of dry and instable conditions during dripstone growth. The structure of speleothems from pools of Zoolithen Cave is quite dendritic, but the crystals do not show skeletal shape in a crystallographic sense. The afore mentioned authors did not respond to a potential undulosity of the crystals in the dendritic fabric.

At present, speleogroups from Bochum and Mainz (Germany) are working together on stalagmites and pool calcites of Zoolithen Cave in combination with laboratory experiments to find more clues to convergent/divergent crystal growth. Preliminary results concerning mineralization in water films suggest a predominance of stalagmite layers with convergent crystal structure within several stalagmites of caves with dolomitic host rocks (Niggemann \& 
Richter, 2006, Wassenburg et al., 2012). Currently performed laboratory experiments using solutions of different $\mathrm{Mg} / \mathrm{Ca}$ ratio suggest a relationship of crystal nucleation to the respective crystal faces of calcite (Schreuer, oral comm.). This corresponds to crystal formation in cave pools.

Summing up, the here presented data document the full petrographic complexity of cave carbonate fabrics. The validity of state-of-art technological approaches in the characterization of the complex three-dimensional texture of these precipitates is shown. A further understanding on the controlling reasons requires a combination of field and laboratory experiments including the strict control (laboratory) and monitoring (cave) of physico-chemical and environmental parameters.

\section{SUMMARY}

Non-ideal calcite crystals from rimstone pools in dolostone caves have been studied for their threedimensional c-axis orientation using the electron backscatter diffraction method (ESBD). The two studied locations (cave pools, Zaunikhalle, Windspalte) from the central part of Zoolithen Cave in Germany yield filigreed speleothem structures (crusts) with different internal calcite lattice structure.

From a three-dimensional viewpoint, both of these calcitic cement crusts are composed of a texturally complex array of bundles of calcite fibers. Remarkably, the fibers of the Zaunikhalle location show a 3D diverging c-axis orientation whilst those of the Windspalte sampling location display a 3D converging c-axis orientation.

The underlying mechanism of this abnormal c-axis behavior of the fibrous calcites of pure calcite composition (similar to Iceland spar) is considered. The free $\mathrm{Mg}$ aquo ions are derived from the Franconian dolomite and transported in the cave setting by aquifer waters into the sinter basin where they are incorporated into calcite at 4-6 $\mathrm{mol}_{\mathrm{O}} \mathrm{MgCO}_{3}$.

The mechanistic reasons for different orientation of the c-axes in the calcite samples investigated (diverging or converging c-axes in growth direction) are at present not understood. Possible reasons might include variable degrees of $\mathrm{Mg}$ saturation of mother fluids promoting convergence of the calcite lattice structure. Experimental work and field monitoring campaigns are instrumental have a significant potential for the improved understanding of these enigmatic fabrics.

\section{ACKNOWLEDGEMENTS}

Sampling and testing were made possible through the courtesy of E. Ziegler (tenant of the Zoolithen Cave). For technical assistance we thank M. Conrad and M. Harder (Cave Research Group "Höhle und Karst Franken e.V."), A. Schröder-Ritzrau (University Heidelberg) and M. Born, S. Schremmer, T. Meyer and A. Niedermayr (Ruhr University Bochum). N. Look kindly improved the English. The critical reviews of A. Hood, B.P. Onac, V. Polyak, and an anonymous reviewer are greatly appreciated.

\section{REFERENCES}

Day A. \& Trimby P., 2004 - Channel 5, HKL-Technology, Hobro, Denmark.

Dreyer R., 2000 - Die Zoolithenhöhle bei Burggaillenreuth (FränkischeAlb-RevisionskartierungundEreignisabfolge. Bochumer geologische und geotechnische Arbeiten, 55: 153-167.

Folk R.L. \& Assereto R., 1976 - Comparative fabrics of length-slow and length-fast calcite and calcitized aragonite in a holocene speleothem, Carlsbad Caverns, New Mexico. Journal of Sedimentary Petrology, 46 (3): 476-496.

Frank N., Braum M., Hambach U., Mangini A. \& Wagner G., 2000 - Warm period growth of travertine during the last interglacial in Southern Germany. Quaternary Research, 54: 38-48.http://dx.doi.org/10.1006/qres.2000.2135

Frisia S. \& Borsato A., 2010 - Karst. In: Alonso-Zarza A.M. $\&$ Tanner L.H. (Eds.), Carbonates in continental settings: Facies, environments and processes. Developments in Sedimentology. Elsevier, Amsterdam: 269-318.

Frisia S., Borsato A., Fairchild I.J. \& McDermott F., 2000 - Calcite fabrics, growth mechanisms and environments of formation in speleothems from the Italian Alps and Southwestern Ireland. Journal of Sedimentary Research, 70 (5): 1183-1196.

Füchtbauer H. \& Richter D.K., 1975 - Undulose extinction in carbonate petrography. IXth International Congress of Sedimentology, Theme 7: 55-61.

Füchtbauer H. \& Richter D.K., 1988 - Karbonatgesteine. In: Füchtbauer H. (Ed.), Sedimente und Sedimentgesteine. Elsevier, Stuttgart: 233-434.

Given R.K. \& Wilkinson B.H., 1985 - Kinetic control of morphology, composition and mineralogy, composition and mineralogy of abiotic sedimentary carbonates. Journal of Sedimentary Petrology, 55: 109-119.

Heller F., 1972 - Die Forschungen in der Zoolithenhöhle bei Burggaillenreuth/Ofr. - 200 Jahre wissenschaftliche Forschung 1771 - 1971. Erlanger Forschungen, Reihe B (Naturwissenschaften), 5: 7-56.

Hill C.A. \& Forti P., 1997 - Cave minerals of the world. $2^{\text {nd }}$ Edition. National Speleological Society, Huntsville, Alabama: 463 p.

Kendall A.C., 1985 - Radiaxial fibrous calcite: a reappraisal. In: Schnermann N. \& Harris P. M. (Eds.), Carbonate cements. Society of Economical Paleontology, Mineralogical Special Publication, 36: 59-77.

Massonne H.J. \& Neuser R.D., 2005 - Ilmenite exsolution in olivine from the serpentinite body at Zöplitz, Saxonian Erzgebirge - microstructural evidence using ESBD. Mineralogical Magazine, 69: 119-124. http://dx.doi.org/10.1180/0026461056920239

Meyer S. \& Dorsten I., 2009 - Die Riesenberghöhle Norddeutschlands größtes Höhlensystem in Jurakalken. Die Höhle, 60 (1-4): 88-93.

Miao S.J., D'Alnoncourt R.N., Reinecke T., Kasaktin I., Berens M., Schlögel R. \& Muhler M., 2009 - A study of the influence of composition on the microstructural properties of $\mathrm{ZnO} / \mathrm{Al}_{2} \mathrm{O}_{3}$ mixed oxides. European Journal of Inorganic Chemistry, 2009: 910-921.http://dx.doi.org/10.1002/ejic.200800987

Neuser R.D. \& Richter D.K., 2007 - Non-marine radiaxial fibrous calcites-examples of speleothems proved by electron backscatter diffraction. Sedimentary Geology, 194: 149154. http://dx.doi.org/10.1016/j.sedgeo.2006.05.015

Niggemann S., Habermann D., Oelze R. \& Richter D.K., 1997 - Aragonitisch/calcitische Koralloide in Karbonathöhlen unterschiedlicher Mg-Betonung. Speläologisches Jahrbuch - Verein für Höhlenkunde in Westfalen, 1995/96: 151-168.

Niggemann S. \& Richter D.K., 2006 - Ein mittelpleistozäner Aragonitstalagmit aus der B7-Höhle (NW-Sauerland, Nordrhein-Westfalen). Die Höhle, 57: 47-56. 
Onac B.P., 1997 - Crystallography of speleothems. In: Hill C.A. \& Forti P. (Eds.), Cave minerals of the world. National Speleological Society, Huntsville, Alabama: 230-236.

Railsback L.B., 2000 - An atlas of speleothem microfabrics. http://www.gly.uga.edu/railsback/speleoatlas/ SAindex1.html

Richter D.K. \& Riechelmann D.F.C., 2008 - Late Pleistocene cryogenic calcite spherolites from the Malachitdom Cave (NE Rhenisch Slate Mountains, Germany): origin, unusual internal structure and stable $\mathrm{C}-\mathrm{O}$ isotope composition. International Journal of Speleology, 37 (2): 119-129. http://dx.doi.org/10.5038/1827-806X.37.2.5

Richter D.K. Neuser R.D., Schreuer J., Gies H. \& Immenhauser A., 2011 - Radiaxial-fibrous calcites: a new look on an old problem. Sedimentary Geology, 239: 2336. http://dx.doi.org/10.1016/j.sedgeo.2011.06.003
Self C.A. \& Hill C., 2003 - How speleothems grow: a guide to the ontogeny of cave minerals. Journal of Cave and Karst Studies, 65 (2): 130-151.

Tietz G.F., 1988 - Zur Genese rezenter Karbonatbildungen in Dolomithöhlen Frankens. Karst und Höhle, 1988: 7-79.

Wassenburg J.A., Immenhauser A., Richter D.K., Jochum K.P., Fietzke J., Deininger M., Goos M., Scholz D. \& Sabaoui A., 2013 - Climate and cave control on Pleistocene/Holocene calcite-to-aragonite transitions in speleothems from Morocco: elemental and isotopic evidence. Geochimica Cosmochimica Acta, 92: 23-47. http://dx.doi.org/10.1016/j.gca.2012.06.002

Wurth G., 2002 - Klimagesteuerte Rhythmik in spätbis postglazialen Stalagmiten des Sauerlandes, der Fränkischen Alb und der Bayerischen Alpen. Dissertation Ruhr-University Bochum, 123 p + Appendix. 